\title{
DIAMONDS FROM THE COROMANDEL AREA, MINAS GERAIS, BRAZIL
}

\author{
FELIX V. KAMINSKY ${ }^{1,2}$, OLGA D. ZAKHARCHENKO ${ }^{2}$, GALINA K. KHACHATRYAN ${ }^{2}$ \& ANDREI A. \\ SHIRYAEV ${ }^{3}$
}

\begin{abstract}
Over one thousand diamonds from the Rio Sao Francisco and Rio Paranaba basins have been comprehensively studied. In addition to characterization of diamond morphology and microanalysis of mineral inclusions, ultraviolet, infrared (IR) and mass-spectrometry techniques were used to constrain elemental and isotopic compositions of these diamonds. The regional specificity of diamonds from the Coromandel area consists of the predominance of rounded rhombododecahedral crystals, the relatively high proportions of crystals with brown pigmentation spots, and a high proportion of crystals with marks of intense mechanical erosion. Based on IR-characteristics, Coromandel diamonds belong to the most common Group $2 \mathrm{~b}$, with $\mathrm{C}_{\mathrm{A}}+\mathrm{C}_{\mathrm{B}}=400$ to 1000 at.ppm, along with South African and Siberian diamonds, while their nitrogen aggregation proportions \% $\mathrm{N}_{\mathrm{B}}=100 \mathrm{~N}_{\mathrm{B}} /$ $\left(\mathrm{N}_{\mathrm{A}}+\mathrm{N}_{\mathrm{B}}\right)$ indicate that Coromandel diamonds belong to the transitional Group 2 with $\% \mathrm{~N}_{\mathrm{B}}=35$ to $75 \%$, along with Yakutian and Venezuelan diamonds. The set of Coromandel diamonds show $\delta^{13} \mathrm{C}$ values varying from -1.5 to $-11.1 \%$, with a peak between -3 and $-7 \%$. The overwhelming majority of diamonds appear to be isotopically 'heavy', i.e, show $\delta^{11} \mathrm{C}>-10 \%$. $95 \%$ of the diamonds with mineral inclusions contain ultramafic ( $\mathrm{P}$ type) inclusions: olivine, enstatite, pyrope, chromian spinel and sulfides. Only two diamonds are E-type; they contain omphacite inclusions. The predominance of minerals of ultramafic association among the mineral inclusions in Coromandel diamonds indicates that the kimberlite magma originated in an ultramafic environment, at approximately $150-200 \mathrm{~km}$ depth, and diamonds are from a homogeneous mantle source of carbon. The similar character of all diamonds from the Rio da Prata system may indicate a common provenance, alternatively they may have originated from sources that are distinct but closely related to each other. The Northern Area is situated closer to the inferred diamond provenance than the Ribeira do Peixe Area. There are probably some areas in Coromandel, where diamonds came to placer deposits directly from primary source(s).
\end{abstract}

Keywords: diamond, Brazil, Coromandel, carbon isotope, nitrogen, inclusions

INTRODUCTION The Coromandel area in the Minas Gerais State, Brazil, is known as 'the land of the great diamonds'. Since the first discovery of diamonds in the Abaeté River in the latter part of the 18 th century, more than 30 stones of 100 carats and more in weight have been recorded (Reis 1959, Barbosa 1991, Svisero 1994). It is said that thirty to forty percent of all the world's largest diamonds were found in the Coromandel area. Large stones are accompanied by numerous small diamonds, but their spatial relationship shows no regularity to date. Previous studies of mineral inclusions in diamonds from the Coromandel area (Meyer \& Svisero 1975, 1980, Svisero \& Valarelli 1977, Mitchell \& Giardini 1977, Svisero 1981, 1983) have been undertaken, but no systematic, comprehensive study of diamonds themselves were done.

No commercial primary diamond deposits are known in the area, although many companies are prospecting for diamondiferous kimberlite/ lamproite pipes in the Coromandel area.

The main objectives of this work were to generate the first comprehensive mineralogical study of Coromandel diamonds in order to identify their characteristic features, and to evaluate the conditions of their formation and deposition.

INFORMATION ABOUT SAMPLES For our study, we used 1055 diamonds from the Coromandel area purchased from local miners ('garimpeiros'). The majority of the stones are from the Rio Sao Francisco basin, mainly from the Rio da Prata system. Geographically, they were subdivided into three groups:

1) - 356 diamonds from the Northern Area (Córrego Sto. Antônio, Córrego Espírito Santo, Grota do Pimpim and Porto do Diamante);

2) - 653 diamonds from the Ribeiro do Peixe Area (including Córrego Corgão, Córrego Fundo, Córrego Imbé, Córrego das Pedras, Grota do Matheus, Grota do Barracão, Córrego da Tapera, Córrego do Lobo, Córrego Lajinha, Córrego da Criminosa), and

3) - 13 diamonds from the Córrego do Salitre area (including Córrego Grotão).

Twenty diamonds are from the Rio Abaeté system, and thirteen diamonds are from the upper reaches of the Rio Paranaíba basin. The weight of diamonds ranged from $10-20 \mathrm{mg}$ to two carats. The diamond numbers in the text and tables consist of the site number and the numerical figures of the stone at the locality.

ANALYTICAL METHODS Analytical work included characterization of diamond morphology and their optical and mechanical properties, ultraviolet luminescence, infrared spectroscopy, carbon isotopic composition, and the identification and microprobe analysis of mineral inclusions. All analytical work except carbon isotope analysis was performed at the Institute of Diamonds in Moscow.

The ultraviolet (UV)-induced luminescence of diamond samples was studied with a 'Lusam-R' apparatus. Photolumi-

1 KM Diamond Exploration Ltd., 815 Evelyn Drive, West Vancouver, B.C., Canada, V7T IJI, Tel and Fax (1-604) 925-8755, E-mail: felixvkaminsky@cs.com

2 Institute of Diamonds, Russian Academy of Natural Sciences, Litovskii Blvd. 5/10 apt. 155, Moscow 117593, Russia.

3 Vernadsky Institute of Geochemistry and Analytical Chemistry RAN, Kosygin St. 19, Moscow 117975, Russia. Presently at Institute of Crystallography RAN, Leninskii prospect 59, Moscow 117333, Russia. 
nescence (PL) was induced by a SVD-120A mercury-quartz lamp with an UFS-6 filter.

Infrared (IR) spectra were obtained using a Specord M-80 spectrometer (Karl Zeiss, Jena) with a beam condenser. Spectral resolution was $6-10 \mathrm{~cm}^{-1}$. Concentrations of $\mathrm{A}$ and $\mathrm{B}$ nitrogen centers were calculated according to the IR absorption coefficients specified by Boyd et al. (1994, 1995). For mixed $\mathrm{IaAB}$ diamond type, the Mendelsson \& Milledge (1995) method was used. Errors on the determined concentrations are less than $25 \%$.

Isotope analyses were made in GEOHI, Russia with the VARIAN-MAT-230 mass-spectrometer, with an accuracy of < $0.1 \%$ PDB $\left({ }^{13} \mathrm{C} /{ }^{12} \mathrm{C} \mathrm{PDB}=0.0112372\right)$. After initial preparation, crystals of diamond were oxidized to $\mathrm{CO}_{2}$ using an $\mathrm{O}_{2}$ flow (circular system, $900{ }^{\circ} \mathrm{C}$ ).

Mineral inclusions were extracted from their diamond-hosts by cracking, and analysis of major elements was carried out using a Camebax electron microprobe, with an acceleration voltage $15 \mathrm{kV}$, and a $15 \mathrm{~mA}$ beam current.

\section{MORPHOLOGY OF THE DIAMOND CRYSTALS}

Diamonds from the Coromandel area include octahedra, dodecahedroids and combination-type crystals. Diamonds of cubic habit occur much more rarely, and a few globular diamonds ('balas') were found in Córrego Sto. Antônio, Rio da Prata system. In all samples, dodecahedroids predominate. OD combination crystals are less abundant, octahedra are even less so, and diamonds of cubic habit are very rare (Table 1).

In our description, we used the same system as for diamonds from Venezuela (Kaminsky et al. 2000); some new morphological varieties are described.

Octahedral diamonds. Four groups of diamonds of octahedral habit were distinguished based on the character of development of their growth features:

I. Flat-faced octahedra with sharp or slightly blunted edges. Diamonds of this group seem to be rare in the Coromandel area.

2. Octahedra with stepwise lamellar development of trigonal faces.
3. Octahedra with polycentric development of crystal faces.

4. Octahedra with ditrigonal faces. Narrow curved surfaces are developed instead of sharp edges and apices in these crystals; they correspond crystallographically to [110] faces (Fig. 1). Crystals of this group prevail among octahedral diamonds.

On average, octahedral diamonds comprise $1-15 \%$ in different areas but may, sometimes, be absent (Table 1).

Diamonds of rhombododecahedral habit show a wide variety of rounded dodecahedroidal shapes, from perfect crystals to strongly distorted, irregularly shaped ones. Based on the nature of the distortion, they are subdivided into the following groups:

1) Isometric, non-distorted crystals.

2) Dodecahedroids distorted along the [110] axis. Dodecahedroids showing either elongation or flattening (but not both) along the [110] axis are relatively rare; most commonly, both elongation and flattening are observed on these crystals. They have two well-developed, parallel faces, elongated in a direction parallel to the long diagonal, and perpendicular to the flattening axis (Fig. 2).

3) Dodecahedroids flattened along the [111] axis. These rather commonly show spinel-type twins. The degree of flattening in this direction varies from negligible to sufficient to result in pseudoditrigonal crystals.

4) Dodecahedroids elongated along the [111] axis. These crystals have six large faces close to the elongation axis. These faces form hexagonal prisms, which terminate on both sides in blunt trigonal pyramids rotated $60^{\circ}$ relative to each other (Fig. 3).

5) Dodecahedroids elongated along the [100] axis. These crystals have a dipyramidal-prismatic habit (Fig. 4).

6) Dodecahedroids featuring complex distortion, i.e. distorted along several crystallographic directions. These crystals typically exhibit uneven development of faces, which form irregular polygons.

The majority of dodecahedroids are equant, elongated along the [1II] axis and complexly distorted (groups 1, 4 and 6). Only these groups have been found in the Venezuelan

Table I - Morphological types of diamonds in the Coromandel area (\% of stones).

\begin{tabular}{lcccccc}
\hline \multicolumn{1}{c}{ Area } & $\begin{array}{c}\text { Number of } \\
\text { diamonds }\end{array}$ & Octahedra & $\begin{array}{c}\text { Dodeca- } \\
\text { hedra }\end{array}$ & $\begin{array}{c}\text { Combin. } \\
\text { types }\end{array}$ & Cubic habit & Uncertain \\
\hline $\begin{array}{l}\text { Rio São Francisco basin } \\
\text { a) Rio de Prata system }\end{array}$ & & & & & & \\
The Northern Area & 356 & 4,8 & 71,6 & 19,1 & 0,3 & 4,2 \\
$\begin{array}{l}\text { Ribeira do Peixe } \\
\text { Córrego do Salitre }\end{array}$ & 653 & 6,7 & 61,3 & 16,4 & 0,8 & 14,8 \\
$\begin{array}{l}\text { b) Rio Abaeté system } \\
\text { Rio Abaeté }\end{array}$ & 13 & 7,7 & 61,5 & no & 7,7 & 23,1 \\
$\begin{array}{l}\text { Rio Paranaíba basin } \\
\text { Rio Paranaíba }\end{array}$ & 13 & 5,0 & 70,0 & 15,0 & 5,0 & 5,0 \\
$\begin{array}{l}\text { Coromandel area } \\
\text { Total }\end{array}$ & 1055 & 5,9 & 65,2 & 17,2 & 0,8 & 10,9 \\
\hline
\end{tabular}




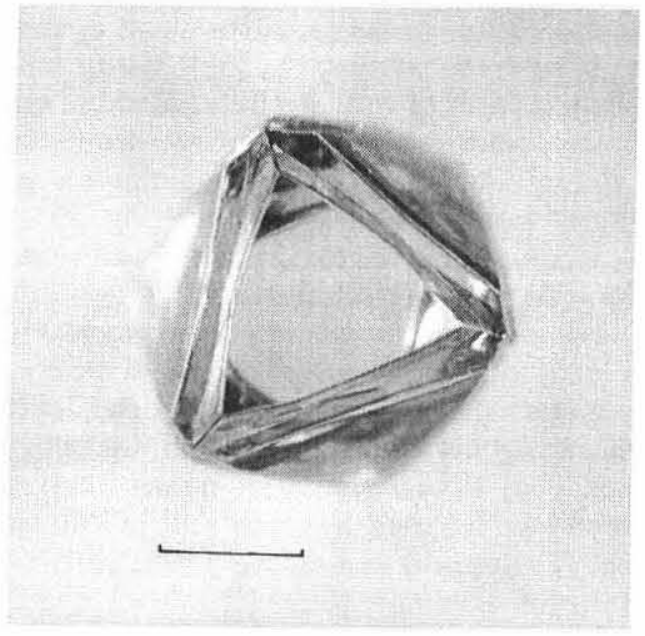

Figure 1 - Octahedron with ditrigonal faces, with grooved curved surfaces at the places of crystal edges. Scale bar is I mim.

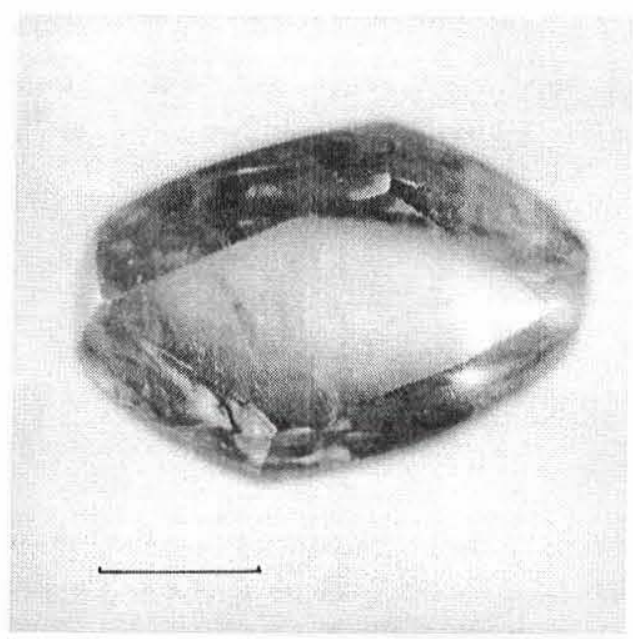

Figure 2 - Dodecahedroid distorted (elongated and flattened) along the [110] axis. Scale bar is $1 \mathrm{~mm}$.

diamonds (Kaminsky et al. 2000). Crystals showing other types of distortion occur much more rarely.

Dodecahedroids, in addition to smooth-faced varieties, frequently show a variety of accessory and surface features on their faces. These diverse surface features of diamond crystals are controlled by three factors: crystallization (growth features), surface dissolution by oxidation reaction, and plastic deformation.

Specific growth features such as laminations, anti-skeleton and polycentric textures result in the formation of some distinctive types of surface features.

Diamond dissolution by oxidation reaction is evidenced by curved surfaces showing a variety of accessory features. Intensive dissolution results in the stripping of defects and internal structural inhomogeneities present in the diamond crystals, and in the appearance of etch channels and pits on crystal surfaces.

Plastic deformation is recorded on crystal surfaces by the

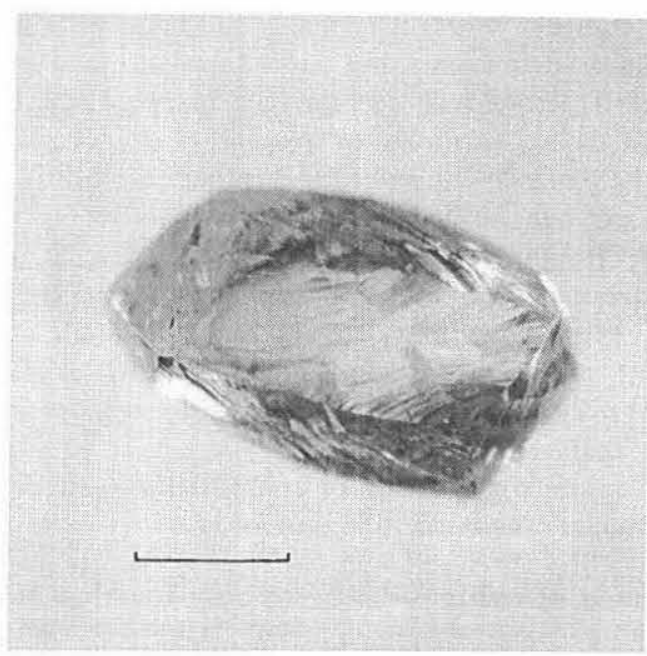

Figure 3 - Dodecahedroid elongated along the [111] axis. Six faces form hexagonal prism at the elongated axis exit point. Scale bar is $1 \mathrm{~mm}$.

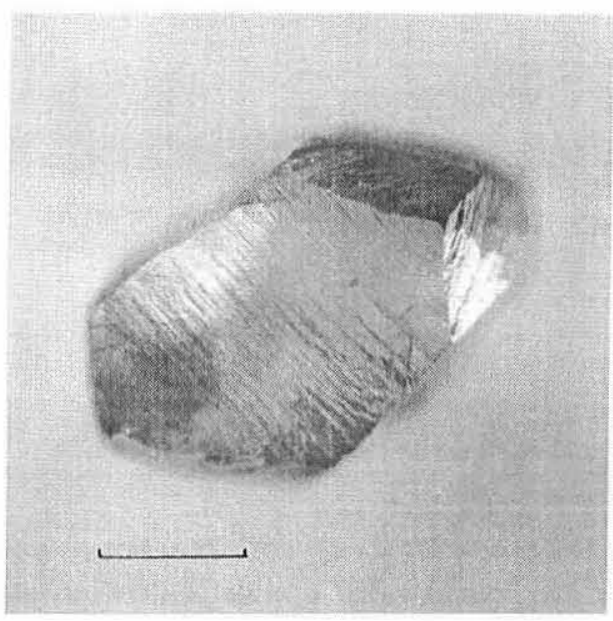

Figure 4 - Dodecahedroids elongated along the [100] axis. Four faces form prism at each of the axis exit point. Scale bar is $1 \mathrm{~mm}$.

emergence of gliding dislocations, which result in distinct striations or thick banding. Curved surfaces of diamonds from the Coromandel area exhibit a wide range of features, which have been well documented in curved-faced diamonds from other regions (Kaminsky et al. 2000). These include block-type (Fig. 5), droplet-like, hackly (with hillocks, by Robinson et al. 1989), and shagreen features (Fig. 6), and concentric (sheaflike) striations (Fig. 7).

Rhombododecahedra prevail among Coromandel diamonds; they comprise $48-75 \%$ of the total number of diamonds at each location (Table 1). Smooth-faced dodecahedroids and those with droplet-like surface features and with concentric striation are the most common; the others comprise only $1-5 \%$ of stones at each locality.

Combination-type diamonds. Among them, octahedron + dodecahedron (O-D) combination forms are predominant, with almost evenly developed (111) and (110) faces. They differ 
from octahedra with ditrigonal (111) faces only in the more pronounced development of curved surfaces, and are therefore characterized by very similar face morphology. Octahedral (111) faces are ditrigonal or irregularly shaped. They feature step-like plate development and rather commonly show etch features of trigonal habit.

Apart from O-D combination crystals, a few diamonds of $\mathrm{O}$ D-C (octahedron + dodecahedroid + cube) crystal type were found. Most commonly, (111) faces of such crystals are smooth; pseudorhombododecahedral (110) surfaces show parallel striations, and pseudocubic (100) surfaces show coarse surface features (Fig. 8).

The average proportion of combination-form diamonds in Coromandel area is $15-20 \%$ (Table 1).

Diamonds of cubic habit were only found in some of the

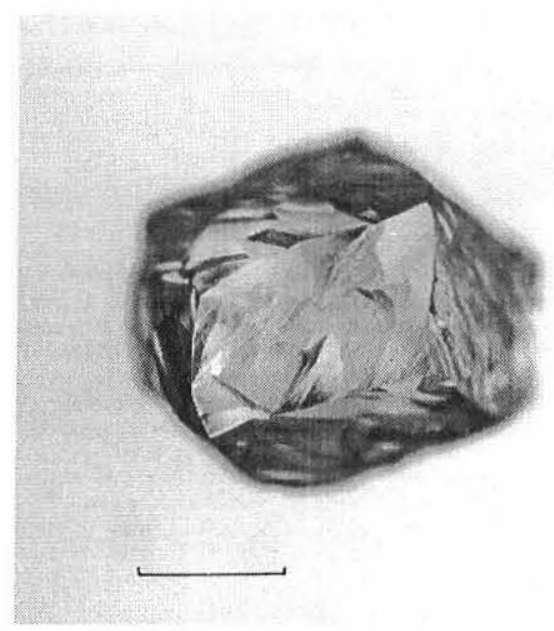

Figure 5-Dodecahedroid with block-type surfaces. The surfaces are composed of distinct blocks of various sizes, shapes and surface curvatures. Blocks are oriented irregularly. Scale bar is $1 \mathrm{~mm}$.

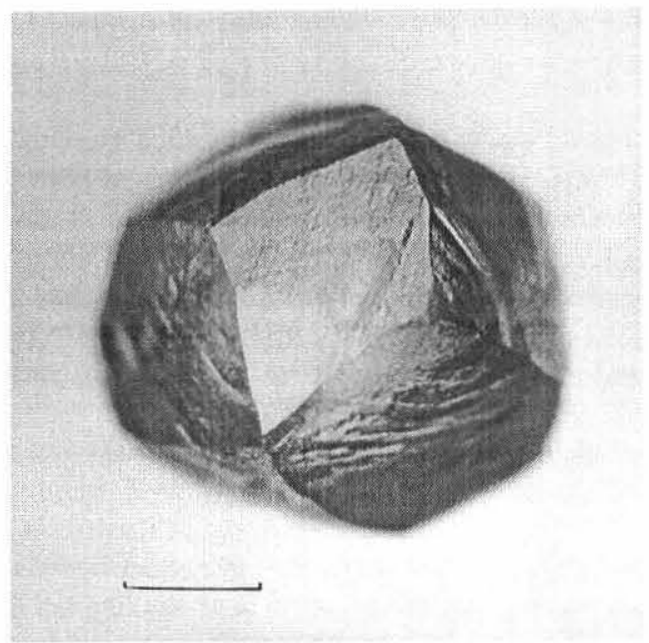

Figure 6 - Dodecahedroid with shagreen surfaces. The surfaces consist of overlapping, very fine hummocks. Scale bar is $1 \mathrm{~mm}$. samples studied, and in very small amounts (less than $1 \%$ of the total). They comprise cubes, cuboids, tetrahexahedroid and combination crystals of cube + tetrahexahedroid type.

Cubes are colorless or pale yellow, semitransparent to opaque. Rather commonly, (100) cubic surfaces show a pattern consisting of numerous tetragonal pits (Fig. 9), and crystal edges are blunted by curved tetrahexahedroidal vicinal surfaces with droplet-like or shagreen features.

Cuboids are opaque crystals of gray to greenish-gray color. All their (100) surfaces are curved and show shagreen features, with small areas showing droplet-like microrelief (Fig. 10).

Tetrahexahedroids are opaque crystals of gray to yellowishgray color. They have a greasy luster and fine-granulose to shagreen surface features (Fig. 11). Small (100) surfaces are sometimes developed at exit points of the [100] axis.

Combination diamonds of cubic habit are combinations of

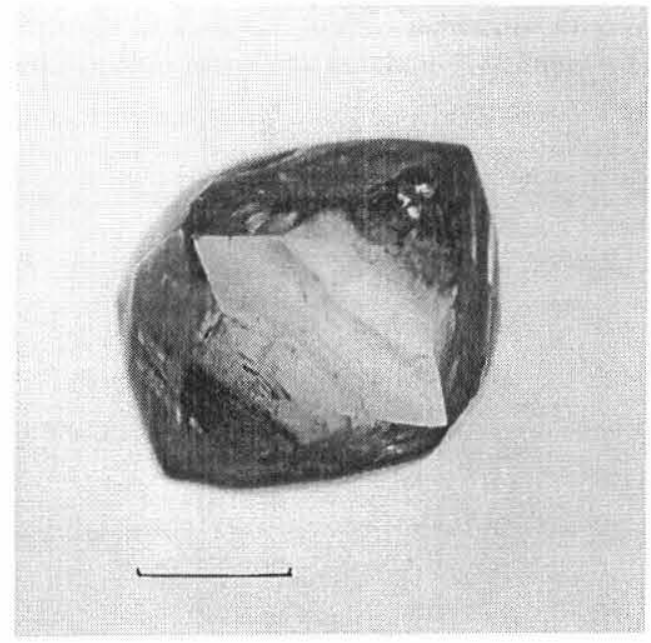

Figure 7 - Dodecahedroid with concentric striations resulting from layer-by-layer crystal growth around exit points of the [1II] axis. Scale bar is $1 \mathrm{~mm}$.

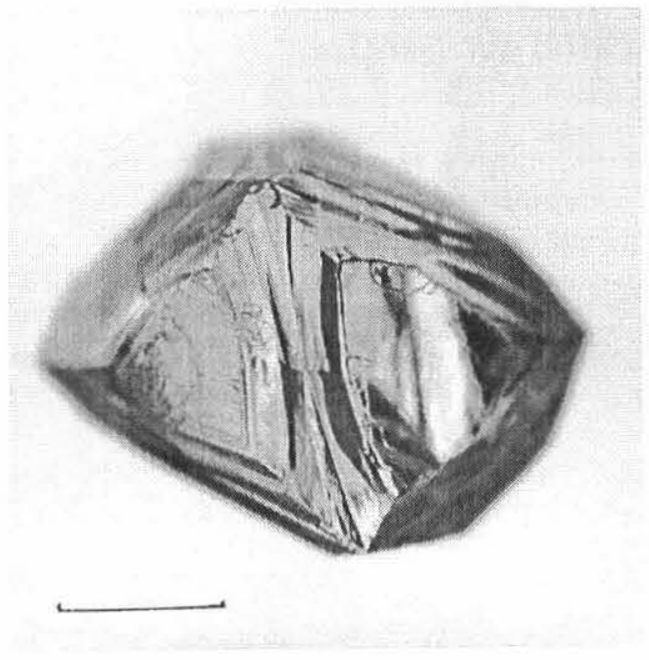

Figure 8 - Diamond of O-D-C (octahedron + dodecahedroid + cube) crystal with sheaf-like striation and curved surfaces. Scale bar is $1 \mathrm{~mm}$. 
flat-faced and curved-faced crystals, which include a cube and a tetrahexahedroid. Most commonly, (100) cubic faces are covered with numerous tetragonal pits. Curved tetrahexahedroidal surfaces are smooth or show small droplet-like hummocks or shagreen surface features.

Twins and aggregates. The average amount of twins and aggregates is low, approximately $10 \%$ in each location. The dominant twin types observed are simple (spinel-type) twins with trigonal and ditrigonal shapes in the case of octahedra and combination crystals, depending on the shape of crystal faces, and with spherical-triangular shapes in the case of dodecahedroids. In addition, there are complex, multiple twins, of which cycle twins of dodecahedroids are most abundant. Also found in the samples studied were parallel and irregular aggregates of crystals of various habits.

Two balases were found in Córrego Sto. Antônio, Rio da

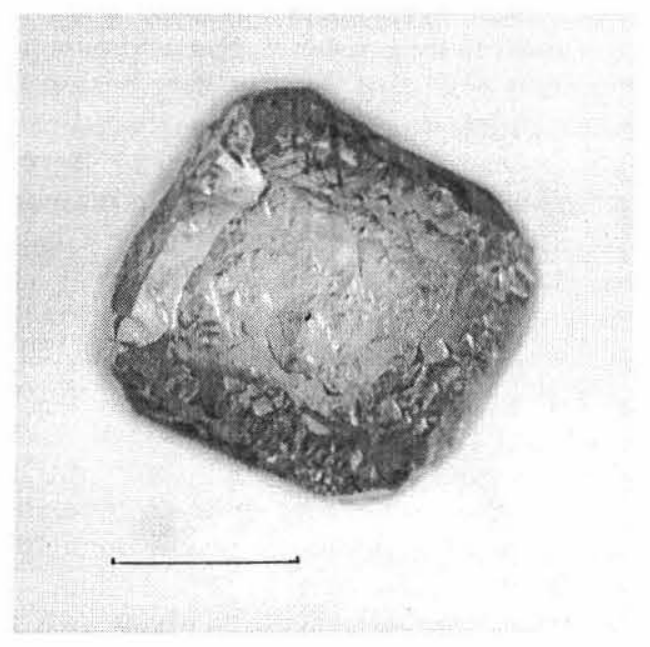

Figure 9 - Cubic crystal with numerous tetragonal pits on (100) faces. Scale bar is $1 \mathrm{~mm}$.

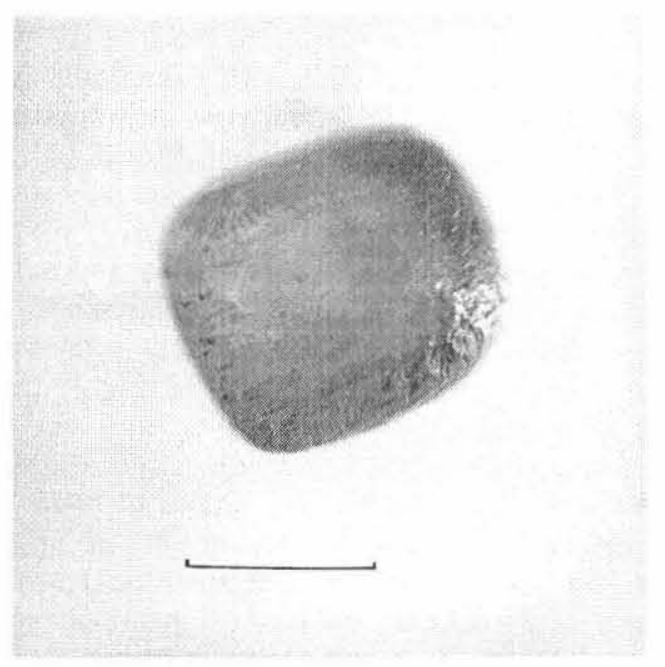

Figure 10 - Cuboid opaque crystal of gray color; with curved (100) faces. Scale bar is $1 \mathrm{~mm}$.
Prata system. These are perfectly spherical, opaque stones showing opalescent bluish-gray coloration (Fig. 12).

The surfaces of these diamonds are distinctively granulose and covered with a continuous pattern of very fine surface joints. Spallation surfaces highlight the radial internal structure of these spherical diamonds. Numerous, very small, dark-colored graphite-like inclusions occur near the surface of these diamonds.

Marks of plastic deformation on the surfaces of diamond crystals consist of gliding lines, which form striations, and coarse deformation bands. In some cases, these bands are accompanied by very small etch trigonal features. Diamonds with plastic deformation bands are relatively rare, accounting for around $9 \%$ of the total number of diamonds.

Oxidative dissolution of diamond surfaces results in the formation of etch channels and vugs. Most commonly, etch channels are developed along zones of weakness, such as

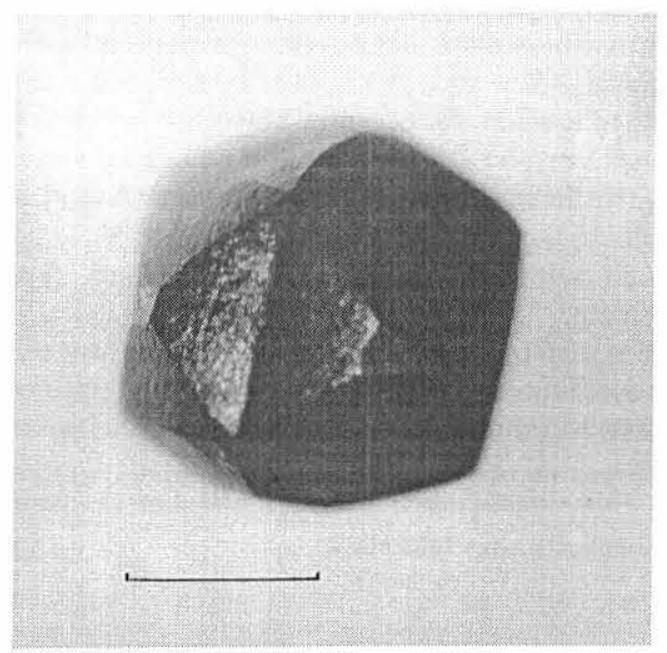

Figure 11 - Tetrahexahedroidal opaque equidimensional crystal of yellowish-gray color. Scale bar is $1 \mathrm{~mm}$.

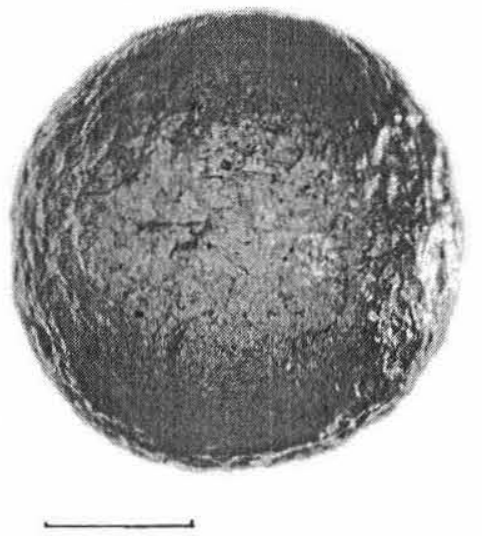

Figure 12 - Opaque balas from Córrego Sto. Antônio, Rio da Prata system. Scale bar is $1 \mathrm{~mm}$. 
joints, cleavages and gliding planes. The channels vary in shape (straight, curved, zig-zag), in width (from thin cracks to broad vugs), in length, and in abundance (from single to numerous channels).

\section{MECHANICAL EROSION OF DIAMOND CRYSTALS}

Among the diamonds studied, both crystals, lacking any evidence of mechanical erosion, and crystals showing various types and intensities of mechanical erosion features were observed. Diamonds lacking evidence of mechanical erosion and those showing only superficial fissures without any 'impact marks' (see below) were found in minor proportions (usually from $5 \%$ to $30 \%$ ). Diamonds with significant mechanical erosion comprise more than $50 \%$ of stones in all locations (Table 2).

There are two types of mechanical erosion observed on Coromandel diamonds: those caused by the alluvial-type transportation, and those which appeared in the coastal-marine environment and are characteristic of diamonds from ancient sedimentary rocks ('intermediate collectors').

In alluvial deposits, diamonds showing marks of mechanical erosion occur alongside diamond crystals showing no evidence of erosion. In the initial stages of mechanical erosion, individual superficial joints develop on crystal surfaces. Most commonly, these joints develop in the proximity of, and perpendicular to the edges of the crystal (Fig. 13A). Other features associated with mechanical erosion of this type consist predominantly of fresh, shiny spallation surfaces with sharp edges (Fig. 13B). The nature of these surfaces ranges from very fine- to medium-sized spallation pits on the edges of complete crystals, to sharp-edged spallation surfaces binding crystal fragments on all sides. Spallation surfaces are typically free of any obvious erosion mark, except for broken or crumbly edges where these are thin and sharp.

Table 2 - Mechanical erosional marks on Coromandel diamonds (\% of stones).

\begin{tabular}{|c|c|c|c|c|c|}
\hline Area & $\begin{array}{c}\text { Number } \\
\text { of diamonds }\end{array}$ & $\begin{array}{l}\text { Single } \\
\text { joints }\end{array}$ & $\begin{array}{c}\text { Numerous } \\
\text { joints }\end{array}$ & $\begin{array}{l}\text { W. rhumbic } \\
\text { pattern }\end{array}$ & $\begin{array}{l}\text { Without } \\
\text { crusion }\end{array}$ \\
\hline \multicolumn{6}{|c|}{ Rio Säo Francisca basin } \\
\hline \multicolumn{6}{|c|}{ a) Rio de Prata ssatem } \\
\hline The Nisthern Area & 356 & 36,2 & 16.9 & 14,0 & 32.9 \\
\hline Riteira do Peixe & 653 & 52,2 & 18.4 & 24.5 & 4.9 \\
\hline Cinregos the Salitre & 13 & $53, x$ & 15.4 & $30, x$ & ms \\
\hline \multicolumn{6}{|l|}{ b) Rio Aluater systrm } \\
\hline Riu Alacté & 20 & 35,0 & 25.0 & 10.0 & 30,0 \\
\hline \multicolumn{6}{|l|}{ Rio Paranaila basin } \\
\hline Rio Paranailua & 13 & 38,5 & 7.7 & no & $53 . x$ \\
\hline \multicolumn{6}{|l|}{ Cormmandel area } \\
\hline Total & 1055 & 46,3 & 17.7 & 20.6 & 15.4 \\
\hline
\end{tabular}

The majority of diamonds from coastal-marine placers show significant evidence of mechanical erosion such as spallation pits, crescent-shaped and annular fissures, blunted and rounded crystal edges and apices, mechanical abrasion marks, and rhombic networks of very fine fissures (Fig. 14).

Experiments have shown such erosion marks to develop only under conditions corresponding to a coastal-marine environment (Dyakov \& Bartoshinsky 1961). The most intensely eroded diamonds undergo superficial spallation, and their crystal edges are destroyed. The resulting grains are globular in shape and have a dull, rough surface.
Most typically, mechanical erosion marks on Coromandel diamond surfaces consist of discrete to numerous fissures (socalled 'impact marks'), which are crescent-shaped or annular, and which control surface relief to variable extents (Fig. 14A). In addition, many diamonds show diamond-shaped patterns on (110) surfaces (Fig. 14B) or peculiar, irregular patterns on (111) faces. These patterns consist of networks of very fine fissures. Neither diamonds with significantly mechanically blunted edges and apices, nor globular diamond grains were found in the collection studied.

Within the Rio da Prata system, placers of Areas 'A' and the Ribeira do Peixe Area appear to be of a 'mixed' origin. It is likely that, in addition to the re-deposition of material derived from old intermediate collector(s) of probable coastal-marine origin, they were formed partly as a result of the direct supply of diamonds from primary source(s), as evidenced by the distribution and nature of mechanical erosion features in these diamonds. The absence of marks of intense erosion, such as mechanically-induced blunting of crystal edges and apices, or of globular diamonds indicate that the diamonds studied probably resided in the coastal-marine environment for only a relatively short period of time, as they passed through the intermediate collector.

The distribution of diamonds based on the character of mechanically induced erosional features is presented in Table 2. Samples from the Northern Area and the Ribeira do Peixe Area are dominated by diamonds showing evidence of mechanical erosion, with a greater predominance of these grains in The Ribeira do Peixe Area than in the Northern Area. This means that the relative contributions of the two types of sources (intermediate collector and direct transport from the primary source) into the placer deposits are different for the Northern Area and the Ribeira do Peixe Area: the Northern Area shows a higher proportion of directly transported material than the Ribeira do Peixe Area.

In one of the localities from the Northern Area, not a single diamond shows marks of mechanical erosion. This suggests that these diamonds were transported under fluvial conditions directly from their primary source. There are probably other areas in Coromandel, where diamonds come to placer deposits directly from primary source(s).

DIAMOND COLOR AND TRANSPARENCY The majority of diamonds from the Rio da Prata system are colorless. Among colored diamonds are yellow, green, brown, smoky-brown, pink and gray grains (Table 3).

The smoky-brown color of many diamonds results from plastic deformation, while grey color is caused by the presence of numerous black graphite-like inclusions (Orlov 1987). Local green and brown coloration is due to pigmentation spots on diamond surfaces. These spots are typically isolated and do not affect the overall coloration of a crystal. In rare cases, these spots occur in clusters.

In the majority of Coromandel diamonds, diamonds with brown pigmentation spots are abundant, and there are occurrences of crystals with a uniform brown coloration. In contrast, in placers of other regions, brown-colored diamonds occur very rarely (only a few crystals with brown, or brown and green pigmentation spots are typically found in other South American placer deposits (Kaminsky et al. 2000, 2001)).

A comparison of the distribution of diamonds by color in samples from the Northern Area and the Ribeira do Peixe Area 

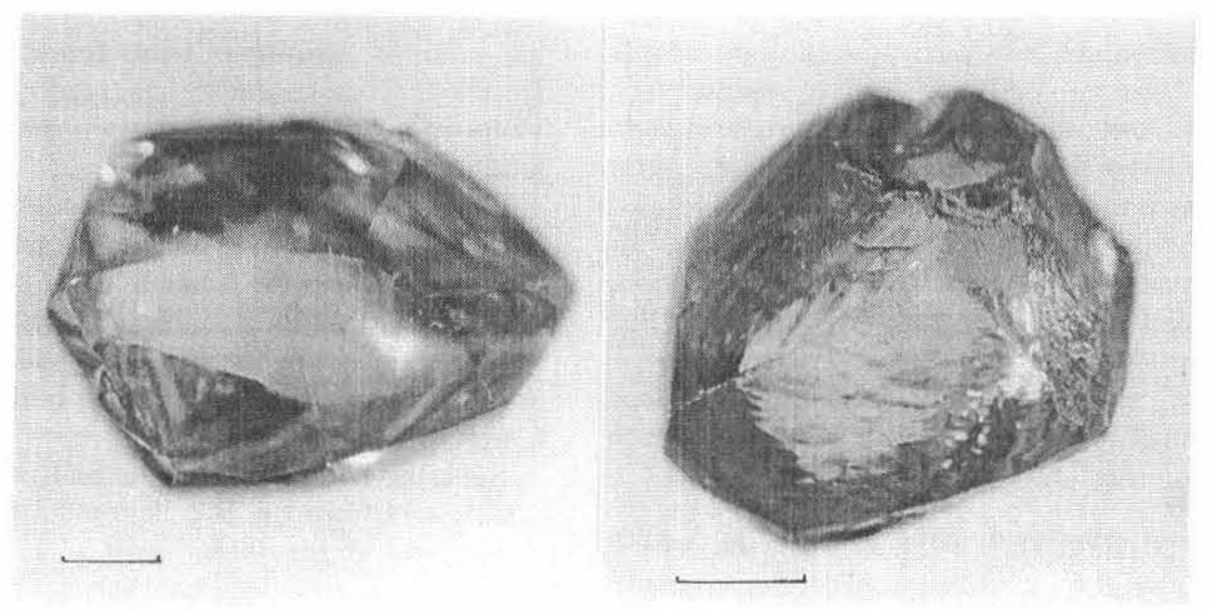

Figure 13 - Alluvial erosion marks on rhombododecahedral diamonds: A - discrete, perpendicular to edges surface joints, B blunted edges and a spalled fragment. Scale bar is I mm.

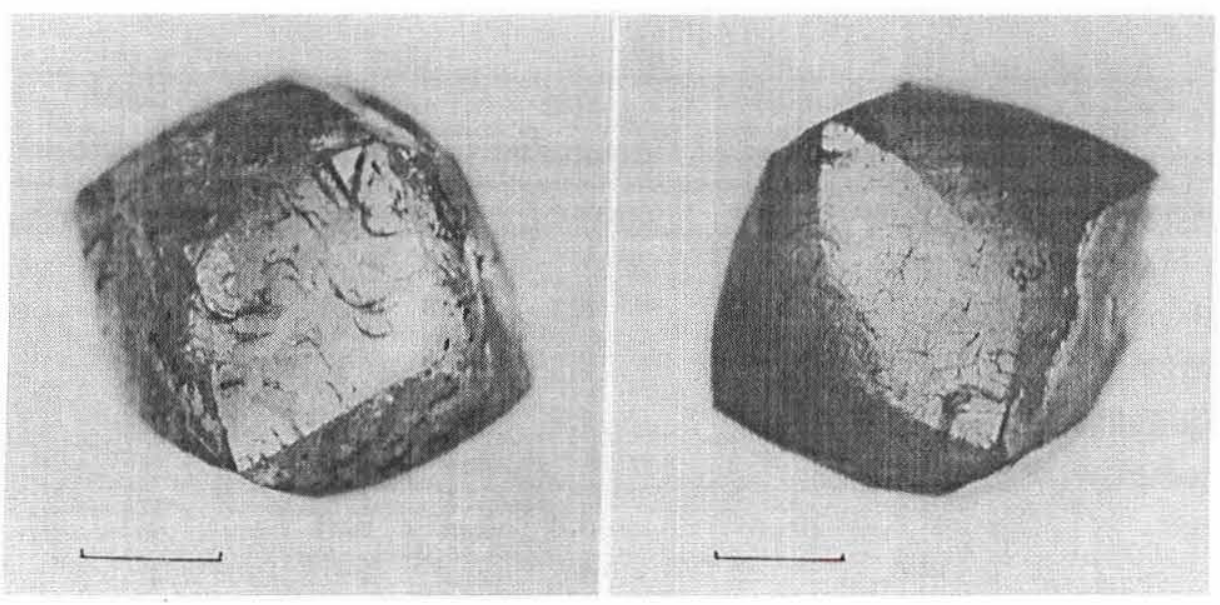

Figure 14 - Coastal-marine erosion marks on rhombododecahedral diamonds: A - large crescent-shaped surface joints, B rhombic surface pattern. Scale bar is I $\mathrm{mm}$.

Table 3 - Coloration of Coromandel diamonds (\% of stones).

\begin{tabular}{|c|c|c|c|c|c|c|c|c|c|}
\hline Area & $\begin{array}{l}\text { Number of } \\
\text { diamonds }\end{array}$ & Colorless & $\begin{array}{l}\text { Smoky } \\
\text { brown }\end{array}$ & Grey & Green & Brown & Yellow & $\begin{array}{l}\text { with green } \\
\text { pigm.spots }\end{array}$ & $\begin{array}{l}\text { with brown } \\
\text { pigm.spots }\end{array}$ \\
\hline \multicolumn{10}{|c|}{ Rio Säo Francisco basin } \\
\hline \multicolumn{10}{|c|}{ a) Rio de Prata system } \\
\hline The Northern Area & 356 & 47,1 & 15,2 & 19.1 & 13,2 & 2,0 & 3,4 & 49,7 & 10,9 \\
\hline Ribeira do Peixe & 653 & 60,0 & 25,2 & 5,4 & 3,4 & 0,8 & 5,2 & 27,6 & 11,2 \\
\hline Córrego do Salitre & 13 & 69,2 & 15,4 & 15,4 & no & no & no & 15,4 & 6,9 \\
\hline \multicolumn{10}{|l|}{ b) Rio Abaeté system } \\
\hline Rio Abaeté & 20 & 50,0 & 30,0 & 15,0 & 5,0 & no & 15,0 & 35,0 & 20,0 \\
\hline \multicolumn{10}{|l|}{ Rio Paranaíba basin } \\
\hline Rio Paranaíba & 13 & 23,1 & 46,1 & 7,7 & 23,1 & no & no & 30,8 & 23,1 \\
\hline \multicolumn{10}{|l|}{ Coromandel area } \\
\hline Total & 1055 & 54,8 & 22,1 & 10,4 & 7,0 & 1,4 & 4,3 & 34,9 & 11,2 \\
\hline
\end{tabular}

shows that the Northern Area is characterized by relatively low proportions of green and brown diamonds and, in general, relatively high proportions of smoky-brown and colorless crystals. The proportion of diamonds with green pigmentation spots in samples from the Northern Area is much higher than in those from the Ribeira do Peixe Area. Smoky-brown diamonds (crystals with plastic deformation) prevail in samples from the Rio Abaeté system and the Rio Paranaíba basin.

The majority of Coromandel diamonds are semi-transparent $(45-92 \%)$ (Table 4). 
Diamond distributions based on transparency in samples from the Northern Area are similar to those in samples from the Ribeira do Peixe Area, although the Northern Area has a lower relative abundances of very transparent, semitransparent and non-transparent stones and higher relative abundances of transparent diamonds. In addition, the combined total number of transparent and very transparent diamonds in samples from the Northern Area is higher than that for the Ribeira do Peixe Area.

In samples from Córrego do Salitre, from the Rio Abaeté system and from the Rio Paranaíba basin, semi-transparent diamonds tend to prevail.

DIAMOND PHOTOLUMINESCENCE The majority of diamonds show blue, green or uncertain photoluminescence (PL). Diamonds, which show yellow PL, are somewhat rarer (Table 5). Many diamonds show no luminescence. In some of the samples, diamonds were found, which show spatially inhomogeneous luminescence (predominantly, blue + yellow). There is no correlation between diamond morphology and luminescence characteristics.

Comparison of the luminescence properties of diamonds from the Northern Area and the Ribeira do Peixe Area reveals that the Northern Area has a lower proportion of diamonds, which do not luminesce, higher abundances of crystals with yellow or uncertain luminescence, and approximately the same proportion of diamonds with blue, green or uncertain luminescence.

Samples from Córrego do Salitre, from the Rio Abaeté system and from the Rio Paranaíba basin are dominated by diamonds with blue luminescence.

INFRARED SPECTROSCOPY AND NITROGEN IMPURITIES Structural impurities in natural diamond

Table 4 - Transparency of Coromandel diamonds (\% of stones).

\begin{tabular}{|c|c|c|c|c|c|}
\hline Area & $\begin{array}{c}\text { Number } \\
\text { of diamonds }\end{array}$ & $\begin{array}{c}\text { Very } \\
\text { transparent }\end{array}$ & Transparent & $\begin{array}{c}\text { Semi- } \\
\text { transparent }\end{array}$ & $\begin{array}{c}\text { Non- } \\
\text { transparent }\end{array}$ \\
\hline \multicolumn{6}{|c|}{ Rio São Francisco basin } \\
\hline \multicolumn{6}{|c|}{ a) Rio de Prata system } \\
\hline The Northern Area & 356 & 6,2 & 30,3 & 46,6 & 16,9 \\
\hline Ribeira do Peixe & 653 & 9,2 & 27,7 & 58,2 & 4,9 \\
\hline Córrego do Salitre & 13 & 7,7 & no & 92,3 & no \\
\hline \multicolumn{6}{|l|}{ b) Rio Abaeté system } \\
\hline Rio Abaeté & 20 & 5,0 & 10,0 & 45,0 & 40,0 \\
\hline \multicolumn{6}{|l|}{ Rio Paranaíba basin } \\
\hline Rio Paranaíba & 13 & no & 7,7 & 84,6 & 7,7 \\
\hline \multicolumn{6}{|l|}{ Coromandel area } \\
\hline Total & 1055 & 7,9 & 27,8 & 54,8 & 9,5 \\
\hline
\end{tabular}

Table 5 - Photoluminescence of Coromandel diamonds (\% of stones).

\begin{tabular}{|c|c|c|c|c|c|c|c|}
\hline Area & $\begin{array}{l}\text { Number of } \\
\text { diamonds }\end{array}$ & $\begin{array}{c}\text { Non- } \\
\text { fluorescent }\end{array}$ & Blue & Green & Yellow & Uncertain & $\begin{array}{l}\text { Inhomo- } \\
\text { geneous }\end{array}$ \\
\hline \multicolumn{8}{|c|}{ Rio São Francisco basin } \\
\hline \multicolumn{8}{|c|}{ a) Rio de Prata system } \\
\hline The Northern Area & 356 & 16,3 & 33,7 & 18,8 & 6,2 & 14,6 & 10,4 \\
\hline Ribeira do Peixe & 653 & 22,7 & 32,3 & 18,0 & 3,8 & 17,5 & 5,7 \\
\hline Córrego do Salitre & 13 & 23,1 & 38,4 & 30,8 & 7,7 & no & no \\
\hline \multicolumn{8}{|l|}{ b) Rio Abaeté system } \\
\hline Rio Abaeté & 20 & 15,0 & 50,0 & 15,0 & no & 10,0 & 10,0 \\
\hline \multicolumn{8}{|l|}{ Rio Paranaíba basin } \\
\hline Rio Paranaíba & 13 & 23,1 & 53,8 & 23,1 & no & no & no \\
\hline \multicolumn{8}{|l|}{ Coromandel area } \\
\hline Total & 1055 & 20,4 & 33,5 & 18,6 & 4,4 & 15,9 & 7,2 \\
\hline
\end{tabular}


reflect the conditions of formation and mantle residence of diamonds and may be used as a 'fingerprinting' tool (Kaminsky et al. 1988). More than twenty types of nitrogen impurities occur in diamonds, as well as hydrogen and boron impurities. In this work we used infrared (IR) spectroscopy to estimate the concentrations of two major nitrogen impurity types: the A-nitrogen centre, which is a pair of nitrogen atoms jointly replacing a single carbon atom (Davies 1976), and the B-defect, which is an aggregate of nitrogen atoms tetrahedrically arranged around a carbon vacancy (Bursill \& Glaisher 1985). We have analyzed 130 diamonds from four different areas within the Rio da Prata system: Córrego Espirito Santo (Sample \#3) and Grota do Pimpim (Sample \#5) in the Northern Area, Córrego Imbé (Sample \#6) and Córrego da Criminosa (Sample \#11) in the Ribeira do Peixe Area (Table 6).

All the diamonds studied belong to the transitional $\mathrm{IaAB}$ type, where the A- and B-nitrogen centres ('defects') occur together. In general, in Coromandel diamonds, B-center is more abundant than A-center, although in some diamonds the opposite is true. In addition, a few low-nitrogen diamonds were found in samples \#3, \#6 and \#11. But in general, the abundance of A-type center varies only slightly (50-300 at.ppm). In most diamonds studied, abundances of B-type center show a similar variability, although its concentration (100-400 at.ppm) is higher than the concentration of A-type impurity.

Comparing to other diamonds worldwide, Coromandel diamonds belong to the most common type based on their nitrogen impurities. By the total nitrogen content, they are in Group $2 \mathrm{~b}$ with $\mathrm{N}_{\mathrm{A}}+\mathrm{N}_{\mathrm{B}}=400$ to 1000 at.ppm, together with South African and Siberian diamonds. By the nitrogen aggregation proportion $\% \mathrm{~N}_{\mathrm{B}}=100 \mathrm{~N}_{\mathrm{B}} /\left(\mathrm{N}_{\mathrm{A}}+\mathrm{N}_{\mathrm{B}}\right)$, Coromandel diamonds belong to the transitional Group 2 with $\% \mathrm{~N}_{B}=35$ to $75 \%$, together with Yakutian and Venezuelan diamonds (Kaminsky \& Khachatryan 2001). By both parameters, Coromandel diamonds differ greatly from Juina diamonds in Mato Grosso State, Brazil, which are low-nitrogen, highly nitrogen aggregated diamonds (Kaminsky et al. 2001).

Diamonds from all samples show a number of similarities (Figure 15). In all the four areas studied, diamonds with a value of $\mathrm{N}_{\mathrm{A}}=130-240$ at.ppm and $\mathrm{N}_{\mathrm{B}}=265-280$ are predominant. However, there are distinctions between the different diamond sets. Diamonds from Córrego Imbé have the lowest $\mathrm{N}_{\mathrm{A}}$ value (mode at 130 at.ppm, against 200-230 at.ppm in diamonds from the Northern Area). Diamonds from Córrego da Criminosa (Sample \#11) show bimodal distributions of nitrogen in both A- and B-forms. They have major peaks and minor, low-nitrogen ones: at $240 \mathrm{ppm}$ for A-type and at $250 \mathrm{ppm}$ for B-type impurities, and at 85 and at $80 \mathrm{ppm}$ respectively. This points to a probable, additional primary source(s) of diamonds in the Northern Area, where lownitrogen crystals are predominant.

\section{CARBON ISOTOPIC COMPOSITION OF DIAMONDS}

A total of 70 diamonds from Rio da Prata system were analyzed for carbon isotope composition. Thirty-six of these diamonds were from samples from the Northern Area, and the remaining thirty-four crystals analyzed were from the Ribeira do Peixe Area (Table 7).

The set of Coromandel diamonds shows $\delta^{13} \mathrm{C}$ values varying from -1.5 to $-11.1 \%$, with a peak between -3 and $-7 \%$. The
Table 6 - Nitrogen impurities in Coromandel diamonds (at.ppm).

\begin{tabular}{|c|c|c|c|c|}
\hline Area, Parameter & $\mathrm{A}, \mathrm{ppm}$ & $\mathrm{B}, \mathrm{ppm}$ & Total & $\% \mathrm{~B}$ \\
\hline \multicolumn{5}{|c|}{ Córrego Espírito Santo, Córrego Charco et al. $(n=32)$} \\
\hline Average & 269 & 351 & 618 & 57 \\
\hline Mode & 200 & 280 & 570 & 45 \\
\hline Standard deviation & 141 & 242 & 319 & 14 \\
\hline From & 17 & 26 & 43 & 30 \\
\hline To & 681 & 1052 & 1590 & 83 \\
\hline \multicolumn{5}{|c|}{ Grota do Pimpim $(n=34)$} \\
\hline Average & 234 & 277 & 508 & 54 \\
\hline Mode & 230 & 270 & 520 & 55 \\
\hline Standard deviation & 155 & 153 & 266 & 11 \\
\hline From & 43 & 57 & 100 & 30 \\
\hline To & 747 & 812 & 1155 & 83 \\
\hline \multicolumn{5}{|l|}{ Côrrego Imbé $(n=32)$} \\
\hline Average & 257 & 357 & 614 & 58 \\
\hline Mode & 130 & 270 & 550 & 55 \\
\hline Standard deviation & 237 & 189 & 384 & 14 \\
\hline From & 5 & 29 & 34 & 35 \\
\hline To & 1126 & 792 & 1918 & 92 \\
\hline \multicolumn{5}{|c|}{ Córrego da Criminosa, all diamonds $(n=32)$} \\
\hline Average & 206 & 280 & 486 & 58 \\
\hline Mode & & 280 & 550 & 55 \\
\hline Standard deviation & 127 & 176 & 290 & 10 \\
\hline From & 5 & 17 & 22 & 47 \\
\hline To & 485 & 929 & 1314 & 80 \\
\hline \multicolumn{5}{|c|}{ Córrego da Criminosa, main maximum $(n=2 l)$} \\
\hline Average & 279 & 357 & 635 & 55 \\
\hline Mode & 240 & 250 & 550 & 55 \\
\hline Standard deviation & 86 & 162 & 231 & 6 \\
\hline From & 151 & 154 & 305 & 47 \\
\hline To & 485 & 929 & 1314 & 70 \\
\hline \multicolumn{5}{|c|}{ Córrego da Criminosa, additional maximum $(n=11)$} \\
\hline Average & 62 & 130 & 192 & 68 \\
\hline Mode & 85 & 80 & 145 & 75 \\
\hline Standard deviation & 37 & 82 & 111 & 11 \\
\hline From & 5 & 17 & 22 & 52 \\
\hline To & 125 & 282 & 407 & 80 \\
\hline
\end{tabular}

overwhelming majority of diamonds appeared to be isotopically 'heavy', i.e., show $\delta^{13} \mathrm{C}>-10 \%$. In this respect Coromandel diamonds are similar to diamonds from the Juina area, Mato Grosso, Brazil (Kaminsky et al. 2001).

Only the two diamonds from Porto do Diamante (the Northern Area, Rio do Prata system) appear to be isotopically 'light', with $\delta^{13} \mathrm{C}$ values of $-10.6 \%$ and $-11.1 \%$. One of them (\#1-2) contains an inclusion of omphacite, i.e., a clinopyroxene of eclogitic suite. All the diamonds with ultramafic mineral inclusions (see below) are isotopically 'heavy'.

Among the diamonds analyzed for $\delta^{13} \mathrm{C}$ were octahedra, dodecahedroids and combination crystals. There appears to be no correlation between diamond morphology and carbon isotopic composition.

MINERAL INCLUSIONS IN DIAMONDS Syngenetic mineral inclusions in natural diamonds worldwide fall into three main paragenetic suites: the peridotitic suite (UM- or Ptype), the eclogitic suite (E-type) and the superdeep suite (SDtype), representing diamonds derived from the lower mantle 
Table 7 - Carbon isotope composition of Coromandel diamonds.

\begin{tabular}{|c|c|c|c|}
\hline Diamond & Morphology & $? " 10, \mathrm{C}, 1 / 60 \mathrm{PDB}$ & Mincral inclusiom \\
\hline \multicolumn{4}{|c|}{ The Northern Area } \\
\hline 1.2 & Dodecuahedroid & -10.6 & omphacite \\
\hline $1-3$ & Dodecahedroid & $-11,6$ & \\
\hline $2-7$ & Dodecahedroid & $-6,3$ & olivine \\
\hline $2-8$ & Twin of cxtahedra & $-4,2$ & chromite \\
\hline $2-9$ & Dodecahedroid & $-7,4$ & \\
\hline $2-10$ & Dodecuahedroid & $-6,8$ & \\
\hline $2-11$ & Doxdecahedroid & $-5,2$ & \\
\hline $2-12$ & Doxlecahedroid & -4.0 & \\
\hline $3-17$ & Combination $\mathrm{O}+\mathrm{D}$ & $-4,4$ & \\
\hline $3-40$ & Twin of octahedra & $-6,2$ & \\
\hline $3-44$ & Dodecuahedroid & $-6,6$ & \\
\hline $3-45$ & Dodecahedroid & $-5,4$ & chromite \\
\hline $3-46$ & Doxdecahedroid & $-5,0$ & olivine \\
\hline 3.47 & Octahedron & $-8,9$ & olivine + pyrope \\
\hline $5-1$ & Doxlecahedroid & $-7,9$ & \\
\hline $5-8$ & Octahedron & $-5,9$ & chromite \\
\hline $5-18$ & Dodecuihedroid & -3.7 & \\
\hline $5-62$ & Combination $\mathrm{O}+\mathrm{D}+\mathrm{K}$ & $-5,1$ & pyrope (two) \\
\hline 5.6 .3 & Dodecahedroid & -2.9 & sulfide \\
\hline $5-69$ & Dodecahedroid & -1.5 & \\
\hline $5-70$ & Doxlecahedroid & -5.0 & olivine \\
\hline $5-71$ & Dodectahedroid & $-4,9$ & \\
\hline $5-72$ & Combination O+D & $-6,0$ & olivine + enstittite \\
\hline $5-73$ & Dodecahedroid & $-6,4$ & \\
\hline $5-74$ & Doxdecahedroid & $-4,8$ & \\
\hline $5-75$ & Dodecahedroid & $-3,2$ & \\
\hline $5-76$ & Combination O+D & $-3,4$ & \\
\hline 5.77 & Combination O+D & $-7,8$ & \\
\hline $5-7 x$ & Combination $\mathrm{O}+\mathrm{D}$ & $-7,0$ & \\
\hline $5-79$ & Combination $\mathrm{O}+\mathrm{D}$ & $-3,3$ & \\
\hline $5-80$ & Doxdecahedroid & -7.5 & \\
\hline $5-81$ & Doxlecahedroid & $-5,4$ & \\
\hline $5-83$ & Combination $\mathrm{O}+\mathrm{D}$ & $-2,7$ & olivine \\
\hline $5-84$ & Doxlecahedroid & $-4,0$ & olivine \\
\hline $5-85$ & Dodecahedroid & $-6,8$ & \\
\hline $5-87$ & Dodectahedroid & $-6,6$ & enstatitc \\
\hline
\end{tabular}

and transition zone. These three paragenetic suites correspond to fundamentally different types of geochemical environment during diamond growth (Meyer 1982, Harte \& Harris 1994).

Results of studies of inclusions in Brazilian diamonds have been previously reported in Meyer \& Svisero (1975, 1980), Svisero \& Valarelli (1977), Mitchell \& Giardini (1977), and Svisero (1981, 1983). It was established, that P-type inclusions are predominant among Brazilian diamonds, although some Etype inclusions are present as well (Mitchell \& Giardini 1977).

We have found and analyzed 50 high-pressure mineral inclusions in 42 Coromandel diamonds. $95 \%$ of the diamonds with inclusions belong to the ultramafic association (P-type); the other 5\% (two diamonds with omphacite inclusions) are of the eclogitic suite.

High-pressure mineral inclusions of ultramafic association (P-type) found in the samples studied include olivine, orthopyroxene, pyrope garnet, chromian spinel, and sulfide.

Olivine is the most common mineral inclusion in the Coromandel diamonds. A total of 29 olivine inclusions were found and analyzed; they are all very similar in their composition (Table 8). The forsterite component in these inclusions varies from 92 to $95 \%, \mathrm{Cr}_{2} \mathrm{O}_{3}$ varies between 0.02

\begin{tabular}{|c|c|c|c|}
\hline Diamond & Morpholugy & $? " \mathrm{C}, \%$ PDB & Mineral inclusion \\
\hline \multicolumn{4}{|c|}{ The Ribeira do Peixe Area } \\
\hline $6-41$ & Dexdecahedroid & $-4,7$ & olivine \\
\hline $6-42$ & Doxlecahedruid & $-3,8$ & olivine \\
\hline (6-49) & Doxlecahedroid & $-4,0$ & olivine \\
\hline 6.50 & Dodecahedroid & $-5,0$ & \\
\hline $6-52$ & Dexlecahedroid & $-6,9$ & olivine \\
\hline 6-53 & Combination $\mathrm{O}+\mathrm{D}$ & $-3,3$ & \\
\hline $6-54$ & Combination $\mathrm{O}+\mathrm{D}$ & $-4,5$ & olivine + enstatite \\
\hline $6-55$ & Dudecahedruid & $-4,2$ & olivine \\
\hline $6-56$ & Octahedren & $-3,0$ & \\
\hline 6-57 & Combination $\mathrm{O}+\mathrm{D}$ & $-5,3$ & \\
\hline $6-58$ & Dexdecahedroid & $-6,5$ & \\
\hline 6.59 & Aggregate of octahedrat & $-5,3$ & olivine (two) \\
\hline 6-60) & Doxlecahodroid & $-4,0$ & olivine \\
\hline $6-61$ & Doxdecahedroid & $-6,3$ & olivine \\
\hline $6-63$ & Twin of doxlecahedroids & $-5,0$ & olivine (two) \\
\hline $6-65$ & Dixdectahedroid & $-6,5$ & olivine \\
\hline 6-67 & Dexlecahedroid & $-4,9$ & \\
\hline 6- 68 & Dixdecahedroid & $-6,3$ & \\
\hline 6-61) & Twin of dodecahedroids & -7.5 & olivine \\
\hline 6-70) & Octahedron & $-5,1$ & enstatite \\
\hline 6.71 & Dixkecahedroid & $-4,3$ & \\
\hline 6.72 & Twin of dexdecahedroids & -8.2 & \\
\hline $6-73$ & Dexlectilicdroid & $-6,0$ & \\
\hline $6-7.4$ & Twin of deckeahedroids & $-5,2$ & enstatite \\
\hline $6-74 a$ & Combination O+D & $-3,4$ & \\
\hline $6-76$ & Aggregate of octahedra & $-3,1$ & sulfide \\
\hline 6-77 & Combination $\mathrm{O}+\mathrm{D}$ & $-3,1$ & omphacite \\
\hline $6-78$ & Combination $\mathrm{O}+\mathrm{D}$ & $-4,7$ & olivine \\
\hline 6-79 & Dexdecahedroid & $-4,2$ & \\
\hline $6-80$ & Dexlecahliedroid & $-2,9$ & olivine \\
\hline $6-81$ & Twin of dixdecahedroids & $-4,2$ & olivine \\
\hline 7.4 & Dixlecahedroid & $-7,8$ & \\
\hline $7-68$ & Doxlecahedruid & $-7,0$ & \\
\hline $10-1$ & Twin of comb.-type $\mathrm{O}+\mathrm{D}$ & $-8,5$ & \\
\hline $11-1$ & Octahedron & $-8,8$ & \\
\hline$|1-3|$ & Octahcdron & $-6,0$ & \\
\hline $11-32$ & Combination $\mathrm{O}+\mathrm{D}$ & $-1,8$ & pyrope + chromite \\
\hline $11-3.3$ & Combination $\mathrm{O}+\mathrm{D}$ & $-5,4$ & \\
\hline $11-34$ & Dixdccahedroid & $-7,0$ & olivine \\
\hline $11-39$ & Combination $\mathrm{O}+\mathrm{D}$ & $-4,6$ & \\
\hline
\end{tabular}

and $0.18 \%$, and $\mathrm{NiO}$ varies from 0.21 to $0.50 \%$. In this respect, olivine inclusions from the Coromandel diamonds are similar in composition to those from previously studied Brazilian diamonds (Meyer \& Svisero 1980, Svisero 1983), as well as to olivine inclusions in diamonds from other regions.

Orthopyroxene. Seven enstatite inclusions were analyzed. They show a similar composition, with relatively low proportions of $\mathrm{CaO}$ and $\mathrm{Cr}_{2} \mathrm{O}_{3}$ admixtures (Table 8).

Chrome-pyrope garnet. Four chrome-pyrope inclusions were analyzed. All of them are subcalcic garnets of harzburgite-dunite association. Such garnets are known to be the dominant garnet type among $\mathrm{Mg}$-rich pyrope inclusions in diamonds from numerous deposits around the world (Sobolev 1977). All four garnets analyzed consist of a high-Cr, knorringite-bearing pyrope variety $\left(\mathrm{Cr}_{2} \mathrm{O}_{3}: 5.4-10.3 \mathrm{wt} . \%\right)$ with relatively low iron (FeO: 10-13\%) and $\mathrm{CaO}$ (Table 8).

Chromian spinel (chromite). Six chromian spinel inclusions were analyzed (Table 9).

In these inclusions, $\mathrm{Cr}_{2} \mathrm{O}_{3}$ contents vary between 64.3 and $65.0 \%$, and $\mathrm{Al}_{2} \mathrm{O}_{3}$ contents vary from 6.41 to $7.86 \%$, which is typical of chromian spinel inclusions in diamonds from a majority of diamond deposits worldwide. In the $\mathrm{Al}_{2} \mathrm{O}_{3}-\mathrm{Cr}_{2} \mathrm{O}_{3}$ distribution, three chromian spinels fall within the compositional field representing the majority of chromian 
Table 8 - Chemical composition of silicate mineral inclusions in Coromandel diamonds (wt. \%).

\begin{tabular}{|c|c|c|c|c|c|c|c|c|c|c|c|c|}
\hline Sample & $\mathrm{SiO}_{2}$ & $\mathrm{TiO}_{2}$ & $\mathrm{Al}_{2} \mathrm{O}_{3}$ & $\mathrm{Cr}_{2} \mathrm{O}_{3}$ & $\mathrm{FeO}$ & $\mathrm{NiO}$ & $\mathrm{MnO}$ & $\mathrm{MgO}$ & $\mathrm{CaO}$ & $\mathrm{Na}_{2} \mathrm{O}$ & $\mathrm{K}_{2} \mathrm{O}$ & Total \\
\hline \multicolumn{13}{|l|}{ Olivine } \\
\hline $2 \cdot 7$ & 41,56 & - & - & 0,08 & 6.08 & 0,36 & $0,1.5$ & 51,49 & 0,02 & - & - & 99,74 \\
\hline $3-46$ & 42,09 & - & - & 0.05 & 6,31 & 0,27 & 0.08 & 51.14 & 0,0 I & - & - & 99.95 \\
\hline $3-47 *$ & 42,09 & - & - & 0.07 & 6.45 & 0.50 & 0.05 & 50.74 & 0,03 & & - & 99.93 \\
\hline $5-64$ & 41.65 & - & - & 0.10 & 6,67 & 0.22 & 0.05 & 51.20 & 0,02 & - & - & 99,91 \\
\hline $5-70$ & 41,58 & - & - & 0.09 & 6.88 & 0.16 & 0,19 & 51,16 & 0.02 & - & - & 100,08 \\
\hline $5-72$ & 41,80 & - & $\cdot$ & 0,02 & 6.75 & 0,38 & 0,12 & 50,59 & 0,04 & - & - & 99,70 \\
\hline $5-83$ & 42,02 & - & - & 0.02 & 7.29 & 0,00 & 0,29 & 50.05 & 0,06 & - & - & 99,73 \\
\hline $5 \cdot 84$ & 42.20 & - & - & 0.06 & 7,27 & 0,32 & 0,06 & 49.96 & 0,04 & - & - & 99,91 \\
\hline $6-41$ & 41.25 & - & - & 0,07 & 5,97 & 0,25 & 0.11 & 52,31 & 0,03 & - & - & 99,99 \\
\hline $6-42$ & 41.57 & - & - & 0,08 & 7,12 & 0.40 & 0,13 & 50,18 & 0,06 & - & - & 99,54 \\
\hline $6-49$ & 41,69 & + & - & 0,18 & 6.90 & 0,34 & 0,07 & 50,78 & 0,03 & + & - & 99,99 \\
\hline $6-52$ & 41,89 & - & - & 0,01 & 6.08 & 0,39 & 0,03 & 51,49 & 0,01 & - & - & 99,90 \\
\hline $6-54 *$ & 42,07 & - & - & 0.08 & 5,99 & 0,21 & 0,12 & 51.49 & 0.00 & - & - & 99,96 \\
\hline $6-55$ & 41,91 & - & $=$ & 0,05 & 6,39 & 0,32 & 0.11 & 51,14 & 0,02 & - & - & 99.94 \\
\hline $6-59(1)$ & 41,84 & - & - & 0,11 & 6.59 & 0,27 & 0.16 & 50,67 & 0,00 & - & - & 99.64 \\
\hline $6.59(2)$ & 41,81 & - & - & 0,12 & 7.28 & 0.30 & 0.07 & 50,20 & 0,03 & - & - & 99.81 \\
\hline $6-60$ & 41,72 & - & - & 0,05 & 6.55 & 0.35 & 0,21 & 51,02 & 0,04 & - & - & 99,94 \\
\hline 6.61 & 41,94 & - & - & 0.13 & 6,22 & 0,30 & 0,12 & 50,54 & 0,01 & - & - & 99,26 \\
\hline $6-63(1)$ & 42,05 & - & - & 0.08 & 5,14 & 0,30 & 0.00 & 52.34 & 0,03 & - & - & 99,94 \\
\hline $6-63(2)$ & 41,63 & - & & 0.08 & 5.87 & 0,30 & 0.10 & 51.95 & 0,01 & - & - & 99.94 \\
\hline $6-64$ & 42.29 & - & " & 0.08 & 5.54 & 0.23 & 0,06 & 51,87 & 0,02 & - & - & 100,09 \\
\hline $6-65$ & 41,75 & $\rightarrow$ & - & 0,03 & 7.10 & 0.49 & 0,11 & 50,60 & 0,02 & - & - & 100,10 \\
\hline $6-69$ & 41,95 & - & - & 0,10 & 6.62 & 0.24 & 0,13 & 50.49 & 0.01 & - & - & 99.54 \\
\hline 6.78 & 41,97 & - & - & 0.02 & 5,34 & 0,33 & 0.00 & 52.22 & 0.01 & - & - & 99.89 \\
\hline 6.80 & 41,79 & $=$ & - & 0.04 & 6.97 & 0,32 & 0,19 & 50,52 & 0.01 & - & - & 99.84 \\
\hline $6-81$ & 42,21 & - & - & 0.06 & 5,94 & 0,26 & 0.05 & 51.42 & 0,01 & - & - & 99,95 \\
\hline $7 \cdot 2$ & 42,14 & + & - & 0,04 & 5,21 & 0,32 & 0.10 & 52,11 & 0,03 & - & - & 99,95 \\
\hline $11-34$ & 42.16 & - & - & 0,10 & 6,18 & 0.33 & 0,17 & 50,68 & 0,02 & - & - & 99,64 \\
\hline $16-1=$ & - 41,74 & - & - & 0,08 & 6.70 & 0.39 & 0,05 & 50,67 & 0,04 & - & - & 99,67 \\
\hline \multicolumn{13}{|l|}{ Enstatite } \\
\hline 5.72 & 58,75 & 0,01 & 0,50 & 0.25 & 3,65 & - & 0,11 & 36,25 & 0.37 & 0,00 & 0,00 & 99,89 \\
\hline 5.87 & 58,47 & 0,02 & 0,47 & 0.26 & 3,55 & - & 0.15 & 36.51 & 0,37 & 0,10 & 0,02 & 99.92 \\
\hline $6-54 *$ & 58.08 & 0,00 & 0.47 & 0,38 & $4,3.5$ & r & 0,08 & 35,80 & 0,70 & 0,00 & 0,00 & 99.86 \\
\hline $6-70$ & 58,51 & 0,00 & 0,65 & 0,26 & 3,79 & - & 0,05 & 36,36 & 0,31 & 0,00 & 0,00 & 99,93 \\
\hline $6-71$ & 58,00 & 0.00 & 1,21 & 0,65 & 3.60 & - & 0,11 & 35,95 & 0.33 & 0.10 & 0,04 & 99,99 \\
\hline $6-74$ & 57,95 & 0,04 & 1,11 & 0,64 & 3,68 & - & $0,0.5$ & 36,19 & 0.30 & 0,0 I & 0,00 & 99,97 \\
\hline $16.1 *$ & 57,77 & 0,00 & 1,11 & 0.66 & 4,08 & - & 0,00 & 36.02 & . 0,33 & 0,00 & 0,03 & 100,00 \\
\hline \multicolumn{13}{|l|}{ Omphacite } \\
\hline 1.2 & 55.97 & 0.72 & 8.51 & 0,02 & 6,18 & - & 0.00 & 9,30 & 13,91 & 4,68 & 0.62 & 99.91 \\
\hline $6-77$ & 56,08 & 0.69 & 10,96 & 0,10 & 5.00 & - & 0,04 & 8,33 & 12,75 & 5,33 & 0,62 & 99.90 \\
\hline \multicolumn{13}{|c|}{ Pyrope Garnet } \\
\hline $3.47 *$ & 42,43 & 0.11 & 16,75 & 8.60 & 4.84 & - & 0.16 & 24,84 & 2.17 & * & - & 99,90 \\
\hline $5-62(1)$ & 41,94 & 0.18 & 15,33 & 10,30 & 5.33 & - & 0,26 & 21,84 & 4.71 & $*$ & - & 99,89 \\
\hline $5.62(2)$ & 43,55 & 0,00 & 18,78 & 5.39 & 5,61 & - & 0,24 & 25.42 & 0,91 & - & - & 99,90 \\
\hline 11.32 & 41,91 & 0,11 & 15,11 & 9.80 & 5,92 & - & 0.27 & 21.79 & 4,80 & - & - & 99,71 \\
\hline
\end{tabular}

Note: Associated with other mineral inclusion(s)

spinel inclusions in diamonds from a number of other regions elsewhere in the world, whereas other three chromian spinel inclusions are characterized by a slightly higher $\mathrm{Al}_{2} \mathrm{O}_{3}$.

Two sulfides were also found included in diamonds. Based on their compositions, in particular their high $\mathrm{Ni}$ content, they are interpreted to be sulfides of ultramafic affinity (Table 10).
High-pressure mineral inclusions of eclogitic association (E-type) are represented by clinopyroxene (omphacite).

Omphacite. Two omphacite inclusions were found in the diamonds studied. In these omphacites, $\mathrm{Na}_{2} \mathrm{O}$ contents vary from 4.7 to $5.3 \%$, and $\mathrm{K}_{2} \mathrm{O}$ is relatively low (0.62\%) (Table 8 ). The chemical composition of the two grains is similar to the 
composition of omphacite inclusions in Brazilian diamonds reported previously (Mitchell \& Giardini 1977), as well as from other regions worldwide.

Three diamonds have composite inclusions: \#3-47, 6-54 and 16-1. Equilibrium temperatures and pressures for these paragenetic associations were calculated using the O'Neill and Wood (1979) and Finnerty \& Boyd (1978) methods for the olivine-pyrope association, MacGregor (1974) and Harvig \& Smith (1982) methods for the olivine-enstatite association, O'Neill \& Wall (1987) and MacGregor (1974) methods for olivine, enstatite and chromite association (Table 11). Pressuretemperature conditions are in a limit of $925-1487^{\circ} \mathrm{C}$ under 54 $70 \mathrm{kbar}$, what corresponds to approximately 150-200 km depth.

\section{DISCUSSION AND CONCLUSIONS The regional} specificity of diamonds from the Coromandel area predominantly consists of rounded rhombododecahedral crystals, with relatively high proportions of crystals with brown pigmentation spots, and a high proportion of crystals with marks of intense mechanical erosion. Among rhombododecahedral diamonds, there are numerous varieties in shape and surface features. It is typical of the pipes with low- to medium diamond grade, but the primary sources are not yet discovered.

Based on the indicator minerals associated with the Coromandel diamonds, and on mineral inclusions in them we may suppose that these primary sources are typical kimberlites. The sharp predominance of minerals of ultramafic association among the mineral inclusions in Coromandel diamonds indicates that kimberlite magma originated in an ultramafic environment, at approximately 150-200 km depth (Table II).

The mafic (eclogitic) component was insignificant: only $4 \%$ of diamonds contain E-type mineral inclusions. This coincides with the data on carbon isotope composition. The vast majority of diamonds are isotopically 'heavy' with their $\delta^{13} \mathrm{C}$ values varying within a very narrow range, which is characteristic of P-type diamonds, and only two diamonds appeared to be isotopically 'light', one of them with an eclogitic-type inclusion. This indicates that the majority of Coromandel diamonds had a homogeneous mantle source of carbon.

Based on a similarity of a number of characteristics (the presence and distribution of the main morphological types and varieties, the low overall abundance of twins in the diamonds studied, the nature of oxidative dissolution, the photoluminescence properties, the proportions of the various nitrogen impurity centers, the carbon isotopic composition, and the concentrations of inclusions of high-pressure minerals), all diamonds from the Rio da Prata system (probably, except Córrego do Salitre) are generally similar, which indicates that they may have a common provenance, or originated from sources that are distinct, but closely related to each other.

The IR characteristics of diamonds also suggest that diamonds from all localities within the Coromandel area are likely to be derived from a common primary source(s). Some differences between the various localities, particularly the bimodal distribution of diamonds, may have two plausible interpretations.

One scenario (which is more likely) is that the bimodal character of the distributions for diamonds from Córrego da Criminosa (Sample \#11) implies two distinct primary sources for the placer deposit sampled. Source I would have been a source for diamonds with higher concentrations of nitrogen
Table 9 - Chemical composition of chromites included in Coromandel diamonds (wt. \%).

\begin{tabular}{lrrrrrrr}
\hline \multicolumn{1}{c}{ Sample } & \multicolumn{1}{c}{$\mathrm{TiO}_{2}$} & \multicolumn{1}{c}{$\mathrm{Al}_{2} \mathrm{O}_{3}$} & \multicolumn{1}{c}{$\mathrm{Cr}_{2} \mathrm{O}_{3}$} & \multicolumn{1}{c}{$\mathrm{FeO}$} & \multicolumn{1}{c}{$\mathrm{MnO}$} & \multicolumn{1}{l}{$\mathrm{MgO}$} & \multicolumn{1}{c}{ Total } \\
\hline $2-8$ & 0,10 & 6,41 & 64,29 & 14,05 & 0,23 & 14,48 & 99,56 \\
$3-45$ & 0,01 & 7,86 & 65,09 & 10,10 & 0,22 & 16,33 & 99,61 \\
$5-8$ & 0,04 & 6,56 & 64,27 & 13,62 & 0,24 & 14,92 & 99,65 \\
$11-32 *$ & 0,18 & 6,78 & 65,04 & 13,49 & 0,37 & 13,96 & 99,82 \\
$16-1(1)^{* * *}$ & 0,07 & 7,64 & 64,55 & 10,72 & 0,37 & 16,28 & 99,63 \\
$16-1(2)^{* *}$ & 0,04 & 7,46 & 64,77 & 10,30 & 0,23 & 16,72 & 99,52 \\
\hline
\end{tabular}

Note: " In association with pyrope ( $\sec$ Table $\mathrm{x}$ )

** In association with olivine and enstatite (see Table 8)

Table 10 - Chemical composition of sulfide included in Coromandel diamonds (wt. \%).

\begin{tabular}{lllllllll}
\hline Diamond & $\mathrm{Fe}$ & $\mathrm{Ni}$ & $\mathrm{Cu}$ & $\mathrm{As}$ & $\mathrm{Se}$ & $\mathrm{S}$ & Total \\
\hline $5-63$ & 46,73 & 15,10 & 0 & 0 & & 0 & $38,(16$ & 99,89 \\
$6-76$ & 42,27 & 19,43 & 0 & 0 & 0 & 38,29 & 99,99 \\
\hline
\end{tabular}

Table 11 - Equilibrium temperature and pressure conditions for mineral associations included in Coromandel diamonds.

\begin{tabular}{llcc}
\hline Sample & \multicolumn{1}{c}{ Mineral association } & Temperature, ${ }^{\circ} \mathrm{C}$ & Pressure, $\mathrm{kb}$ \\
& & & \\
\hline $3-47$ & olivine + pyrope & 1287 & 69,7 \\
$6-54$ & olivine + enstatite & 925 & 54,2 \\
$16-1$ & olivine + enstatite + chromite & 1245 & 58,6 \\
\hline
\end{tabular}

structural impurities, which are common for the other areas, and an additional source II may have supplied low-nitrogen diamonds.

A second scenario, which is speculative, but should not be excluded, is based on the regularity that diamonds with a higher concentration of segregation-type nitrogen impurities (B-centers) are more resistant to mechanical erosion (Naletov et al. 1979). In this case diamonds from Córrego da Criminosa may have been derived from the same type of the initial source, but that source was located much closer than for all the other samples.

After emplacement of the primary sources, the diamonds underwent a long history in their evolution and deposition in recent placer deposits. Epigenetic mechanical features of Coromandel diamonds are the most important feature in understanding this process. Corrosion marks on Coromandel diamonds demonstrate that a significant number of stones were reworked in a coastal-marine environment. They bear spallation pits, crescent-shaped and annular fissures, blunted and rounded crystal edges and apices, and others, which are characteristic of the coastal-marine reworking. The same stones frequently have brown pigmentation spots. The experiments have shown that brown pigmentation spots on natural diamonds are a result of the transformation of the green ones when the diamonds are heated to $500-550{ }^{\circ} \mathrm{C}$ (Orlov 1987). If that is the case, then the high abundance of diamonds with brown pigmentation spots suggests that the history of 
these diamonds involved residence in high-temperature (500$550^{\circ} \mathrm{C}$ ) intermediate collectors. This conclusion coincides with our finds of kimberlite indicator minerals (garnet and picroilmenite) in the Lower-Cretaceous Areado Formation, both in samples and in situ in sandstones near Córrego Lobo (F. Kaminsky, unpubl. data).

The other group of mechanically induced marks on diamonds, such as spallation surfaces is of alluvial origin. They are observed on both, fresh and previously mechanically reworked diamonds. This means that diamonds have come to the recent placer deposits both directly from non-discovered primary sources (kimberlites), and from intermediate, ancient, sedimentary collectors.

All placer deposits in the Rio da Prata system appear to be of 'mixed' origin, which is evidenced by the presence of diamonds with alluvial and coastal-marine erosion marks. The relative abundance of diamonds with intense mechanic erosion marks is higher in the Ribeira do Peixe Area than in the Northern Area.

There is a direct correlation between fluvial transport distance and the proportion of broken crystals (or their fragments). Because jointed crystals are fractured and fragmented, and the resulting fractured and fragmented crystals are transported downstream from the accumulation area, the average weight of diamonds in placer samples tends to increase towards the upper reaches of placer-forming rivers. Conversely, diamond sizes in placers tend to decrease in the downstream direction, provided that no other sources of diamonds occur along the flow direction, which could supply additional diamonds to the placers sampled. There is a close correlation between diamond morphology and resistance to mechanically induced damage resulting from alluvial transport. Rounded and smooth-faced crystals appear to be more resistant to transport, whereas diamonds with lamellar or step-wise, polycentrically developed crystal faces are less resistant. The relatively higher proportions of broken, jointed, and smooth-faced crystals, and the relatively lower abundances of diamonds with well-developed concentric striations and hackly surface features in the Ribeira do Peixe Area than in the Northern Area, suggests that the Northern Area is situated closer to the inferred diamond provenance than the Ribeira do Peixe Area.

In one of the localities from the Northern Area, no diamonds show mechanical erosion marks of coastal-marine environments. Diamonds in this area are statistically different from the diamonds of all other areas. There is a significantly higher abundance of diamonds with combination-type spallation surfaces here, and all broken crystals look very fresh. Diamonds from this area have a large proportion of grey stones; they differ from the other stones in their transparency and average value. The lack of mechanical erosion marks on diamonds here gives a reason to suggest that these diamonds were transported under fluvial conditions immediately from their primary source, and not very far. There are probably other areas in Coromandel where diamonds come to placer deposits directly from primary sources.

Acknowledgements This study of diamonds was financed by Canabrava Diamond Corporation. We thank Rory Moore for the permission to publish this material and to reviewers of RBG for suggestions to the manuscript.

\section{References}

Barbosa O. 1991. Diamante no Brasil; Historico, Occorencia, Prospeccao e Lavra. CPRM, Brasilia, $136 \mathrm{pp}$.

Boyd S.R. Kiflawi I., Woods G.S. 1994. The relationship between infrared absorption and the A defect concentration in diamond. Phil. Mag, B69:1149-1153.

Boyd S.R., Kiflawi I., Woods G.S. 1995. Infrared absorption by the B nitrogen aggregate in diamond. Phil. Mag., B72:351-361.

Bursill L.A. \& Glaisher R.W. 1985. Aggregation and dissolution of small and extended defect structures in type la diamond. Amer. Miner., 70:608-618.

Davies G. 1976. The A nitrogen aggregate in diamond: its symmetry and possible structure. Journ. Phys., C9:L537-L542.

Dyakov A.G. \& Bartoshinsky Z.V. 1961. Transportation and character of erosion of diamonds from alluvial placers of western Yakutia. Yakutsk, IYaFSO AN SSSR, Proceedings , v. 6, p. 133-135 (in Russian).

Finnerty A.A. \& Boyd F.R. 1978. Pressure-dependent solubility of calcium in forsterite coexisting with diopside and enstatite. Ann. Rep. Geophys. Lab. Carnegie Inst. 1978, p. 713-717.

Harte B. \& Harris J.W. 1994. Lower mantle mineral association preserved in diamonds. Mineral. Mag., 58A:384-385.

Harvig R.L. \& Smith J.V. 1982. Temperature-dependent distribution of Ca between olivine and pyroxenes in lherzolite xenoliths. Contr. Min. Petrol., 81:184-189.

Kaminsky F.V., Bartoshinsky Z.V., Blinova G.K., Galimov E.M., Gurkina G.A., Krasnikov V.I., Lapushkov V.M., Sobolev E.V., Sobolev N.V. 1988. Comprehensive study of diamonds for prospecting of primary deposits. Moscow, 88 pp. (in Russian).
Kaminsky F.V. \& Khachatryan G.K. 2002. Characteristics of Nitrogen and other impurities in diamond, as revealed by infrared absorption data. Can. Mineral., 39:1733-1745.

Kaminsky F.V., Zakharchenko O.D., Griffin W.L., Channer D.M.DeR. \& Khachatryan-Blinova G.K. 2000. Diamonds from the Guaniamo area, Venezuela. Canadian Mineralogist, 38:1347-1370.

Kaminsky F.V., Zakharchenko O.D., Davies R., Griffin W.L. \& Shiryaev A.A. 2001. Superdeep diamonds from the Juina area, Mato Grosso State, Brazil. Contr. Mineral. Petrol., 140(5):734-753.

MacGregor I.D. 1974. The system $\mathrm{MgO}-\mathrm{Al}_{2} \mathrm{O}_{3}-\mathrm{SiO}_{2}$ : solubility of $\mathrm{Al}_{2} \mathrm{O}_{3}$ in enstatite for spinel and garnet peridotite compositions. Amer. Miner., 59:110-119.

Mendelssohn M.J. \& Milledge H.J. 1995. Geologically significant information from routine analysis of the Mid-Infrared spectra of diamonds. Internat. Geol. Review, 37:95-110.

Meyer H. O. A. 1982. Mineral inclusions in natural diamond. In: Proc. International Gemological Sympos., Santa-Monica, NY, p. 445-465.

Meyer H.O.A. \& Svisero D.P. 1975. Mineral inclusions in Brazilian diamonds. Phys. Chem. Earth, 9:785-795.

Meyer H.O.A. \& Svisero D.P. 1980. Kimberlites and diamonds in Brazil: Windows to the Upper Mantle. Anais da Academia Brasileira de Clência, 52:819-825.

Mitchell R.S. \& Giardini A.A. 1977. Some mineral inclusions from African and Brazilian diamonds: their nature and significance. Amer. Miner., 62:756762.

Naletov A.M., Klyuev, Yu.A., Grigoryev, O.N. 1979. The effect of optically active 
impurity centres on the damage resistivity of diamonds. Doklady AN SSSR, 246(1):83-86 (in Russian).

O'Neill H.S.C. \& Wall V.J. 1987. The olivine-orthopyroxene-spinel oxygen geobarometer, the nickel precipitation curve, and the oxygen fugacity of the Earth's upper mantle. Journ. Petrology, 28:1169-1190.

O'Neill H.S.C. \& Wood B.J. 1979. An experimental study of Fe-Mg partitioning between garnet and olivine and its calibration as a geothermometer. Contr. Miner. Petrol., 70:59-70.

Orlov Yu.L. 1987. Mineralogy of Diamonds, John Wiley and Sons, NY, 235 pp.

Reis, E. 1959. Os grandes diamantes Brasileiros. Rio de Janeiro, 66 pp.

Robinson D.R., Scott J.A., Van Niekerk A., Anderson V.J. 1989. The sequence of events reflected in the diamonds of some southern African kimberlites. In: Kimberlites and Related Rocks. Vol. 2: Their Mantle/Crust Setting (J. Ross, ed.). GSA Special Publication No. 14. Blackwells, Melbourne, p. 9901000 .

Sobolev N.V. 1977. Deep-Seated Inclusions in Kimberlites and the Problem of the
Composition of the Upper Mantle. American Geophysical Union, Washington, D.C., 279 pp.

Svisero D.P. 1981. Quimica e origem de minerais inclusos em diamantes brasileiros : granadas. Anais da Academia Brasileira Ciências, 53:153-163.

Svisero D.P. 1983. Composicao quimica e origem de minerais inclusos em diamantes brasileiros: olivinas e piroxenios. Anais da Academia Brasileira cience, 55(4): 396- 407.

Svisero D.P. 1994. Distribution and origin of diamonds in Brazil: an overview. In: Internat. Simp. Phys. Chem. Upper Mantle, Sao Paulo, Brazil, p. 257-287

Svisero D.P. \& Valarelli J.V. 1977. Particao $\mathrm{Fe}^{+2} / \mathrm{Mg}$ Entre Olivinas e Ortopiroxenios Coexistentes em Diamantes. Anais da Academia Brasileira Ciência, 49:237-241.

Manuscrito A-1310

Recebido em 28 de novembro de 2001

Revisão dos autores em 27 de dezembro de 2001

Revisão aceita em 28 de dezembro de 2001 